43 | 2009

Les langues entre elles dans les usages et les contextes éducatifs en Europe (XV|e-XX

\title{
Breeze or storm? The European Reform Movement and Dutch Foreign Language Teaching, c1880-1920
}

Frans Wilhelm

\section{(2) OpenEdition}

Journals

Electronic version

URL: https://journals.openedition.org/dhfles/881

DOI: $10.4000 /$ dhfles.881

ISSN: 2221-4038

Publisher

Société Internationale pour l'Histoire du Français Langue Étrangère ou Seconde

Printed version

Date of publication: 1 December 2009

Number of pages: 163-178

ISSN: 0992-7654

Electronic reference

Frans Wilhelm, "Breeze or storm? The European Reform Movement and Dutch Foreign Language

Teaching, c1880-1920", Documents pour l'histoire du français langue étrangère ou seconde [Online], 43 |

2009, Online since 16 January 2011, connection on 27 May 2021. URL: http://

journals.openedition.org/dhfles/881; DOI: https://doi.org/10.4000/dhfles.881

This text was automatically generated on 27 May 2021

(c) SIHFLES 


\title{
Breeze or storm? The European Reform Movement and Dutch Foreign Language Teaching, c1880-1920
}

\author{
Frans Wilhelm
}

\section{Introduction}

1 In retrospect the decades between 1880 and 1920 appear to have had a special significance for foreign language teaching (FLT) in the countries of north-western Europe. These decades are known for what came to be called «the Reform Movement " in language teaching. This paper deals with Dutch FLT in the period c1880-1920 and its relationship with the European Reform Movement. The main questions are if there was anything like a Dutch Reform Movement and, if so, in how far it was influenced by other European countries.

\section{The Reform Movement in the Netherlands : past and present views}

2 I begin by presenting a number of Dutch views, past and present, on the Reform Movement. Some views date from a hundred years ago or more, others are of more recent date. It is claimed by these views that the Reform movement, which caused such a stir in our neighbouring countries, hardly affected the Netherlands.

3 First, we have an eye witness account as early as 1895 by J.J.A.A. Frantzen, who had written a German textbook along the lines of Gouin's method and who was personally committed to language teaching reform :

It may be said that in Germany the supporters of moderate reform of foreign

language teaching have won. In France, England and Scandinavia the movement 
has not yet developed so far, although it is making huge progress. It is difficult to say how the situation is in this country. One hears little about it, partly because everyone minds their own business and does not talk about the reform movement either in personal conversations or at school meetings, and partly because school inspectors do not meddle with classroom practices ${ }^{1}$.

In 1932, some 20 years after the Reform debate had fallen silent, the language scholar Gerlach Royen commented :

French is still taught in the same way as schoolmasters did in Voltaire's time. German is not taught a lot better. Only the teaching of English may be said to be in a more favourable condition(Gerlach Royen 1932, in De Liefde 1936 : 79-88).

5 A few years later, S. Rombouts (1937:168), a teacher educator and pedagogical scholar, claimed that FLT had hardly changed over the preceding 25 years. He describes the influence of the Reform on Dutch FLT as follows :

[...] as for French, German and English, practically everything remained unchanged. It appears that few people gave their thoughts to methodology: otherwise one must have been able to read much more about it in our pedagogical journals. [...] Apparently, the entire movement passed over this country like a fleeting whirlwind or a little storm, rousing no one from their sleep. As regards its influence on the teaching of French, I vaguely remember one or two isolated cases of primary school teachers who hesitantly gave the direct method a try but soon gave up again ${ }^{2}$.

The editor-in-chief of the modern language teacher journal Levende Talen, C.L. de Liefde, showed himself considerably more careful in his survey of twenty-five years of French language teaching (1936: 79-88), pointing out that he had few historical data at his disposal. Also his colleague Baardman (1953 : 549) took a careful stand in his survey of FLT methodology. He simply concluded that by the end of the nineteenth century FLT in Holland was characterised by a great variety of practices. Kuiper (1961 : 133-134) claimed that the Dutch Reform Movement did not have a clear focus and was by no means such a well-organised and centralised movement as in Germany. More recently, Van Els (1992 : 42) stated that, whereas in the surrounding countries there was a "school" with a certain degree of organisation, such a movement did not exist in Holland :

At the time when in other countries of Western Europe proposals for methodological change originated with what looked like "schools or "movements" with some degree of organization, in the Netherlands nothing of the kind emerged. of course, there were proposals for change [...] but there was no organized or concerted action worth mentioning (Van Els $1992: 41-42$ ).

\section{Sources for research}

7 From the above one is inclined to conclude that the Reform Movement in Holland was insignificant and that the influence of the European countries was small. However, the question is on what information these views are based. From the comments of the persons who published their ideas during the 1930s it appears that their knowledge of the historical facts was relatively small. And the comments of later critics do not seem to be based on profound research either. So the question remains if these viewpoints are historically justified. It seems to me that in order to arrive at a well-balanced 
judgement one should investigate at least the following sources (cf. Van Els \& Knops 1988: 291):

-a) historical observations and accounts (e.g. of teacher conferences and meetings, and of classroom practices)

-b) theoretical treatises (brochures, articles, monographs)

-c) textbook materials (titles, prefaces, references, content)

-d) curricula and examination requirements.

8 The study of these sources requires some comment, however. In the first place, historical observations, such as eye-witness accounts, are very rare. The number of reports of historical events is somewhat greater, although they are still few and far between. All this makes the investigation of, for instance, historical classroom practices almost impossible. We do not know what exactly went on in classrooms one hundred years ago. This means that we have to rely on the second best source, historical textbooks. They give us the best possible impression of what went on in foreign language classes at the time, much better than theoretical treatises do. In addition, we have official curricula and examination requirements.

\section{The principles of the International Reform Movement: a very brief sketch}

9 There is little disagreement on the general principles and characteristics of the Reform Movement. That the Reform stressed the role of the spoken language was a result of the fact that the science of speech physiology flourished in the second half of the nineteenth century and that the founding fathers of the Reform, Viëtor, Sweet, Passy and Jespersen, were phoneticians. In fact, if it had not been for the new science of phonetics, the Reform would never have had the success and scientific prestige it enjoyed. After the publication of Viëtor's pamphlet Der Sprachunterricht muss umkehren (1882), which is generally regarded as the official starting-point, a flow of articles, brochures and monographs on language teaching methodology began to appear ( $c$. Aronstein 1926 : 52-58; Howatt \& Widdowson 2004 : 187-198).

10 The name 'Reform' is a broad, comprehensive term, as it does not point to one particular teaching method but refers to various principles grouped together under one heading. Howatt \& Widdowson (2004: 189) mention three basic principles as characteristic of the Reform: «the primacy of speech, the centrality of the connected text as the kernel of the teaching-learning process, and the absolute priority of an oral methodology in the classroom ». They add that, although there were different interpretations of these principles at the time, there was no fundamental disagreement on the direction that the Reform was to take.

The Movement received a lot of support, although it also met with a lot of criticism. Critics attacked the principle that a foreign language was to be taught without the help of the mother tongue and that the use of translations was forbidden. Also the fact that the Reformers rejected teaching explicit grammar rules met with a great deal of opposition. Besides, many critics opposed the idea that learning colloquial speech appeared to be the chief target of FLT and they wondered what would happen to the intellectual and cultural aspects of learning foreign languages. 
In terms of educational policy, the Reform Movement was extremely successful in North-West Europe. It became so influential that in France and Belgium the so-called Direct Method was made compulsory in certain types of schools (cf. Closset $1960: 23-24$; Puren $1988: 101-106)$. The question that concerns us here is in how far these principles and procedures were adopted by the Dutch government and by Dutch foreign language teachers.

\section{Dutch foreign language teaching around 1880 : the main characteristics}

What did Dutch FLT look like around 1880 when the Reform Movement started? It may be characterised as follows:

1. By tradition the Dutch government was reluctant to meddle with teaching methodology. School inspectors occupied themselves with administrative matters rather than with the teaching itself. As a consequence, teachers were free to choose their own methods and materials.

2. There were no teacher training institutes, there was only a tradition of State-conducted examinations and private tuition by experienced schoolmasters ( $c$. Van Essen $1983: 75)$. In 1880 there were no universities that offered foreign languages as degree subjects. If they wished, students could attend private lectures at the four Dutch universities, but they could not take a degree in these subjects. The academic staff hardly took any interest in FLT methodology (Kwakernaak 1996 : 47-50), but were far more concerned with the scholarly content of their subjects.

3. There was no special association of foreign language teachers, although there were various schoolmaster associations. Around 1880 there were only two foreign language teacher journals (Wilhelm 1996 : 14-16). One of them, Taalstudie 1879-1890, functioned mainly as an academic journal presenting articles on literature and linguistics, whereas the other one, De Drie Talen 1885-1987, functioned as a distance-learning tool in as far as it prepared students for teacher examinations.

4. Until the 1880s the dominant FLT methodology had been the grammar-translation method (cf. Wilhelm 2005). However, since the 1830s there had been various attempts to renew or adapt FLT, mostly influenced by textbooks from abroad. Generalizing, one may state that there had been a slow but steady trend towards fewer rules and more and varied exercises and texts.

\section{The Reform Movement in the Netherlands} 1880-1920

How did Dutch teachers get into touch with the Reform and how were its principles worked out? Were there any meetings or conferences where methodology problems were discussed? Were there attempts to set up an FLT journal or an association for foreign language teachers to introduce the ideas of the Reform? Was there anything like an academic discourse?

1. As far as we know, no efforts were made to organise special meetings or conferences to discuss Reform principles. However, from the reports of the general association of teachers in secondary schools (AVMO), founded in 1867, we do know that topics like these occasionally came up for discussion at annual meetings. On these occasions, 
debates and discussions would take place in subsections of the general teachers association, such as the section of modern language teachers. Thus, at the 1894 meeting of the Secondary Schoolmasters Association, a teacher of German, M. Horn, gave a presentation on the "Direct Method». The speech bore the title «FLT in our higher secondary schools can only meet its demands if it is organised according to the Direct Method ». Afterwards, an unpleasant debate followed with the champion of the Gouin method in the Netherlands, L.P.H. Eijkman 3 . From the account that was made of the meeting Eijkman emerges as a rather tactless character who tried to impose his views on his colleagues and in this way managed to frustrate an open debate. Horn was a strong supporter of the Berlitz approach, while Eijkman embodied the Gouin method. The debate illustrates the clash of opinions among some foreign language teachers in the 1890 s and it is this atmosphere that may well have put off other teachers. However, the topic of the Direct Method and of the Reform principles, was intriguing enough in itself to return at teacher meetings in one way or another. In this sense a kind of informal academic discourse may be said to have been going on for some time. Let me give you two more examples. In 1904 J.C.G. Grasé, a well-known teacher of English, read a paper entitled "Something on the Direct Method" at an international conference of language scholars ${ }^{4}$. And in 1912 a (female) teacher of German read a paper ${ }^{5}$ to the newly founded association of modern language teachers Levende Talen on the question « Direct or Indirect Method? ». As a matter of fact the presentation turned out to be a plea for the Gouin method. As usual, the presentations were followed by a debate.

Summarizing, we may state that the Reform discourse did not appeal enough to the Dutch foreign language teachers to devote a conference to them, to set up a journal or a special interest group. However, we must not forget that it was the lack of organisation of these teachers as well as the absence of a journal of their own that made it difficult for them to organise anything in the way of conferences. Besides, there were no regular teacher training institutes where the new ideas could be explained and put into practice. And also the universities kept aloof from the daily practice of FLT. Finally, there were no initiatives on the part of the government to bring about changes in teaching methodology. This area was considered to be the exclusive domain of the teachers themselves. All this resulted in relatively few teachers getting in touch with the Reform principles and thus the Dutch Movement remained largely a matter of individual interest. On the other hand, it is obvious that the Reform principles did appeal to some foreign language teachers and that these principles were the subject of an ongoing discussion.

17 2. The next source that we have to study is historical treatises. The question here is: were there any publications that may be said to have contributed to a debate on the Reform principles? From the 1880s onwards a growing number of articles, brochures and monographs appeared that were clearly inspired by the Reform. The first contribution is a brochure by T.G.G. Valette, a teacher of German, published in 1889, seven years after of Viëtor's pamphlet. It was entitled Het onderwijs in de levende vreemde talen. Valette may be credited with having introduced the Reform in Holland through this publication, as he mentions the main points of it (inductive grammar, oral skills, connected sentences). The brochure was followed by many others. I will restrict myself to the most important ones. In $1892 \mathrm{~J}$. Esmeijer published a treatise entitled Het aanleeren van vreemde talen. In this brochure the author relates how he has been converted to the Berlitz method. I have already shown above how M. Horn, a colleague of Esmeijer's, who also supported the Berlitz method, clashed with Eijkman on the 
principles of the Direct Method. In 1894 Eijkman published an article in the journal De Drie Talen in which he showed himself an advocate of the Gouin method. Two years later, in 1896, J.C.G. Grasé wrote a treatise entitled Directe Methode en Phonetisch Schrift als Grondslagen van Taalonderwijs. In this brochure Grasé presents himself as a representative of the Reform Movement, although he is quite relaxed about its terminology $(1896: 10)$ :

We, Reformers, acknowledge that we owe a lot to all those new and latest methods by Viëtor, Jespersen, Gouin, Berlitz; those conversation, natural and visual methods....They are all different manifestations of one Reform Method or ear method, if I may say so, as different as their teachers.

18 Grasé here leaves a lot of room for interpretation but insists on the importance of the oral skills in accordance with the Reform. He also stresses another point on which the aforementioned « different manifestations » agree $:$ it is the importance of the sentence as the first and foremost object of instruction

Whether one teaches in the spirit of the German and Scandinavian Reformers, or whether one subscribes to Gouin's views, in which he attaches such great value to the verb as the pivot of everything - the different methods agree in this one respect that it is the sentence, the whole sentence that one should teach first, not the word.

It did not take long before the Reform ideas met with opposition. In 1900 F. Prick van Wély wrote an article claiming that schools should not emphasize oral proficiency too much but should instead stress reading as a form of cognitive learning. The chief aim of higher secondary schools should not be skills training but general education or Formalbildung. Furthermore, he added (1900-1901: 102) that there is no " royal road to learning ", a phrase that he had borrowed from Henry Sweet (1899 : vii)(Prick van Wély $1900-1901: 102)$.

20 Above I have referred to Grasé's paper to the Philological Congress of 1904. In this paper Grasé proposed three aims for FLT: 1. introduction to the foreign culture through reading its literature 2. skills training and 3. intellectual education through explicit language knowledge (grammar, phonetics). This viewpoint illustrates how Grasé's ideas had evolved. Although he had called himself a Reformer in 1896, he now took a more moderate view by stressing literary and intellectual education, a view that may be called « eclectic». As such he now seemed to lean towards the ideas expressed by Prick van Wély in 1900. Grasé's viewpoint appears to be representative of the majority of Dutch foreign language teachers.

21 An important if not decisive role in the discourse was played by K. Ten Bruggencate in 1906 with the publication of a series of articles in the journal of the Secondary Teachers Association. As an inspector of secondary schools Ten Bruggencate was a man of authority. In the conflict between supporters of the grammar-translation method and the direct method, he chose the side of the direct method but took a moderate stand. To express his point of view he used a Shakespearean metaphor, when he noted that he had learnt not to stick to one method as the "be-all and end-all", but to use more methods. This series of articles probably expressed the feeling of the majority of teachers that there could not be one solution to the problem of FLT. However, at the same time it probably also provided an excuse for many to carry on with the old routine.

3. The third source is historical textbooks. There has been some research into nineteenth- century textbooks for French, German and Spanish in the Netherlands (Breet \& Ceton 1982 ; Knops 1982) and recently a monograph came out on the history of 
English language teaching (Wilhelm 2005). The latter study demonstrates that in the course of the nineteenth century there were quite a few attempts at innovation that foreshadow the Reform Movement. In other words, the Reform did not come out of the blue but it is clear that there was a previous history. Unfortunately, there is no time to go into detail here. However, what I can tell you is that Dutch FLT has always been strongly influenced by ideas and examples from outside. Therefore, it should not come as a surprise that the titles, prefaces and references in the textbooks after 1880 prove that the European Reform had a great impact on Dutch textbook writers. Of course, one would have to study the content of these textbooks carefully to find out in how far the Reform principles were put into practice. Let me give you a few examples.

First of all, a typical feature is found in the pronunciation sections of textbooks, especially textbooks for English. The textbooks published from about 1880 show a remarkable preoccupation with pronunciation and more specifically with attempts to set up systems of phonetic transcription. These attempts demonstrate how textbook writers were looking for ways to teach the sound system of the foreign language without the interference of the mother tongue. Moreover, we come across frequent discussions about the question which was better: teach the language with or without phonetic transcription ( $c f$. Mertens 1879, Ten Bruggencate 1887 and Grasé 1895).

The titles, prefaces and references of textbooks published after 1880 also indicate other changes in FLT. As early as 1885 the title of a French textbook by T. Boerma claimed that its aim was to teach "in accordance with the direct method" and through visualization. Also the Berlitz method, with its unilingual approach, strong emphasis on oral skills and visual presentation, influenced Dutch textbooks. This method came over from the USA in the 1880s and 1890s and the best-known example in the Netherlands is a German textbook by Esmeijer and Horn dating from 1893. Another influence from abroad was the Gouin method. It was L.P.H. Eijkman who introduced this method in Holland in 1894. As we saw above, he wrote an article about it and, in cooperation with a teacher of French and one of German, he managed to publish a complete Gouin-based course for English, French and German in 1894. The coursebooks were accompanied by an extensive teacher's manual to make sure that the method was applied correctly.

The first Reform-based textbook for English was published by J.H.A. Günther in 1890. It bore the title Leerboek der Engelsche Taal voor Eerstbeginnenden. In the preface he states that his book was « the result of what men such as Sweet, Passy, Viëtor, [....] Klinghardt and others have recently brought about in the field of FLT » and Günther goes on to mention his principles. These are the provision of texts in every-day language, a system of phonetic transcription, an inductive grammar approach and the abolition of texts for translation. The influence of the Reform is even more noticeable in J.C.G. Grasé's English textbooks. His course is significantly entitled Oefeningen in de Engelsche Taal (1895-1896). It is significant, because the title suggests that learners can only learn a foreign language by doing, i.e. through (a lot of) practice. And indeed, the learner has to work his way through a lot of exercises. Grasé, too, offered every-day English texts, a system of phonetic transcription, inductive grammar and a unilingual approach. Like Günther's book, Grasé's course was very successful, which proves that the new method was received well and that foreign language teachers were willing to change their classroom practices ${ }^{6}$. There are many more titles and prefaces of French and German textbooks suggesting that they somehow made use of the Reform principles. These titles and prefaces often use such terms as "Reform », «Direct Method» and «new 
movement». Precisely in how far the Reform principles were applied in these textbooks remains a matter of further study, however.

4. The fourth and last source concerns the official school curricula and examination requirements. What interests us here is the question if and in how far official regulations were changed under the influence of the Reform ideas. The first schoolleaving examinations of higher secondary schools took place in the 1860s. What we see is that, whereas there were no changes before 1900, suddenly some changes took place after 1900 within a short space of time. If before 1900 oral examinations had been optional, from 1901 onwards they became compulsory. It is also interesting to note that from 1901 onwards candidates were no longer required to demonstrate an explicit knowledge of grammar rules. Another point is that alternative examinations formats were introduced for the written part of the examinations. For instance, from 1910 candidates had to listen to a spoken text and write an essay on the subject. Finally, in 1917 pronunciation became a separate part of the oral examination. The nature of these changes suggests that they were made under the influence of the Reform, although it is difficult to prove a causal connection. However, it seems very likely that the Reform ideas were at the bottom of these changes. What other reason could there have been to bring about these alterations in such a short period of time?

\section{Conclusion: breeze or storm?}

On the basis of what has been investigated so far, it seems reasonable to speak of a Dutch Reform Movement in its own right. There were more actions between 1880 and 1920 than was acknowledged by Royen and Rombouts in the 1930s, although I must agree with Van Els (1992:41-42) that the Dutch Reform was largely an action of individuals and not a concerted action. The Reform principles were a recurring item at the meetings of secondary school teachers, which sometimes led to controversies among teachers, but it is unrealistic to speak of an academic discourse that held the majority of foreign language teachers in its spell. It is more likely that the majority were undisturbed by the views that were put forward. They were in a position to do so because it was not the government but the teachers themselves who decided on FLT methodology. On the other hand, it cannot be denied that in these decades there was a mood of willingness to try out new things if we look at the number of treatises after 1880 advocating change in FLT, if we look at the great number of textbooks whose titles and prefaces express a preference for Reform ideas, and if we look at the changes in the official examination regulations after 1900. If I have to characterise the Dutch Reform Movement, I would call it moderate in the sense that the majority took a moderate view of the proposed changes and adopted the new principles slowly but surely. For instance, many textbooks after 1920 used phonetic transcription and introduced texts and oral exercises. Dutch teachers selected what they thought useful and interesting from foreign examples and in this respect the Dutch Reform was different from what went on in many other European countries. In short, here was not a storm but a breeze which kept blowing for a long time. 


\section{BIBLIOGRAPHY}

ARONSTEIN, Philip. 1926. Methodik des neusprachlichen Unterrichts. Leipzig/Berlin : Teubner.

BAARDMAN, G.G. 1953. « Geschiedenis van het onderwijs in vreemde talen tot het einde van de $\mathrm{XIX}^{\mathrm{e}}$ eeuw ». Levende Talen $172: 549$.

BOERMA, T. 1885. De Fransche taal volgens de rechtstreekse methode. [...] 1e stukje: directe aanschouwing. Groningen : J.B. Wolters.

BREET, Gemma de \& CETON, Rineke. 1982. Leerboeken Engels, Frans en Spaans in Nederland: 1796-1900. Inventarisatie, bibliografie en aanzet tot beschrijving. Nijmegen : Instituut voor Toegepaste Taalkunde (unpublished thesis).

BRUGGENCATE, K. ten. 1887. De uitspraak van het Engelsch [...] behoorende bij De Hoofdzaken der Engelsche Grammatica. Groningen : J.B. Wolters.

------1905-1906. «Over taalonderwijs», in: Weekblad voor Leeraren aan Inrichtingen voor Middelbaar Onderwijs. $988 \mathrm{ff}$.

CLOSSET, Fr. 1960. Inleiding tot de didactiek van de levende talen. Groningen.

EIJKMAN, L.P.H. 1894. «Voordracht over het onderwijs in vreemde talen volgens de methode Gouin». in De Drie Talen 1894 : 63-93.

------[1895]. Handboek voor den Onderwijzer ten gebruike bij [...] de Handleiding voor de Beoefening der EngelscheTaal [...] volgens de leerwijze van Gouin. Amsterdam : Allert de Lange.

ELS, Theo J.M. van. 1992. «Foreign language teaching in the Netherlands, 1880-1940: an outline of methodological developments», in Anick Giroud (éd.). Aspects de l'histoire de l'enseignement des langues: 1880-1940. Neuchâtel: Bulletin CILA 56, 35-47.

ELS, Theo J.M. van \& KNOPS, Mathieu F. 1988. « The History of the Teaching of Foreign languages in the Low Countries ", Historiographia Linguistica XV, 1/2 (1988):289-316. Also in J. Noordegraaf, K. Versteegh, K. Koerner (eds.). 1992. The History of Linguistics in the Low Countries. Amsterdam \& Philadelphia : John Benjamins.

ESMEIJER, J. 1892. Het aanleeren van vreemde talen. Rotterdam.

ESSEN, A.J. van 1983. E. Kruisinga. A Chapter in the History of Linguistics in the Netherlands. Leiden : Martinus Nijhoff.

FRANTZEN, J.J.A.A. 1895. Handboek voor den onderwijzer ten gebruike bij het eerste deeltje van de Handleiding voor de beoefening der Hoogduitsche taal ten dienste van eerstbeginnenden en bewerkt volgens de leerwijze van Gouin, Amsterdam : Allert de Lange.

GRASÉ, J.C.G. 1895. Oefeningen in de Engelsche taal. Leerstof for the first three months. Grongen : J.B. Wolters.

------1896. Directe Methode en Phonetisch Schrift als Grondslagen van Taalonderwijs. Groningen : J.B. Wolters.

------1904. « Iets over de Directe Methode ». Handelingen van het Philologencongres. Utrecht. GÜNTHER, J.H.A. 1890. Leerboek der Engelsche taal voor eerstbeginnenden. Groningen : J.B. Wolters. HOWATT, A.P.R. \& Widdowson, H.G. 2004. A History of English Language Teaching. Oxford : Oxford University Press. 
KNOPS, M. 1982. Leerboeken Duits 1668-1917. Aanzet tot een inventarisatie. Nijmegen, Instituut voor Toegepaste taalkunde (unpublished thesis).

KUIPER, W. 1961. Historisch-didactische aspecten van het Duits. Groningen.

KWAKERNAAK, Erik. 1996. Grammatik im Fremdsprachenunterricht. Geschichte und Innovationsmöglichkeiten am Beispiel Deutsch als Fremdsprache in den Niederlanden. (S.l.) Deutsch. Studien zum Sprachunterricht und zur interkulturellen Didaktik.

LIEFDE, C. de. «Over het onderwijs in het Fransch in de laatste vijf en twintig jaar ». Levende Talen $1936: 79-88$.

MERTENS, A.J. 1879. Engelsche Spraakkunst [...]. Eerste deeltje: de uitspraak van het Engelsch onder regels gebracht. Nijmegen : W. Fellinga.

PRICK VAN WELY, F.P.H. 1900. «Het onderwijs in de moderne talen», in Tijdschrift voor Onderwijs en Opvoeding 3, 1900-1901: 97-110.

PUREN, Christian. 1988. Histoire des methodologies de l'enseignement des langues. Paris : Clé International.

ROMBOUTS, S. [1937]. Waarheen met ons vreemde-talenonderwijs? Tilburg.

ROYEN, Gerlach. 1932. In C. de Liefde. « Over het onderwijs in het Fransch in de laatste vijf en twintig jaar ». Levende Talen 1936:79-88.

SWEET, Henry. 1899. The practical study of languages. London : Dent.

Taalstudie. Tweemaandelijks tijdschrift voor de studie der nieuwe talen. Culemborg: Blom \& Olivierse, 1879-1890.

Tijdschrift De Drie Talen voor hen die zich willen oefenen en verder bekwamen in de Fransche, Duitsche en Engelsche taal. Amsterdam : C.L. Brinkman, 1885-1987

VALETTE, T.G.G. 1889. Het onderwijs in de levende vreemde talen. Haarlem : De Erven F. Bohn.

WILHELM, F.A. 1996. « Nederlandse tijdschriften voor de moderne vreemde talen in de negentiende eeuw », Meesterwerk. Berichten van het Peeter Heynsgenootschap 6 (1996) : 12-22.

-----2005. English in the Netherlands. A history of foreign language teaching 1800-1920. With a bibliography of textbooks. Utrecht : Gopher Publishers.

\section{NOTES}

1. Dr. J.J.A.A. Frantzen later became professor of German at Utrecht University. The quote has been taken from the preface to Frantzen's Handboek voor den onderwijzer [Teacher's manual] based on Gouin's method (1895:2).

2. On the same page Rombouts corrects himself in a footnote in which he appears to remember another French textbook, i.e. Eijkman's Methode Gouin, Handboek voor den Onderwijzer.

3. Berichten en Mededeelingen van de Vereeniging van leeraren aan Inrichtingen van Middelbaar Onderwijs. Leeuwarden, 1893-1896:243-264.

4. « Iets over de Directe Methode » in Handelingen van het Philologencongres 1904.

5. «Direkte of indirekte methode? » Paper read to the Association of Modern Language Teachers «Levende Talen» by Mrs. N.E. Labarre-Mulert on 28 May 1912 (Weekblad VIII, 1911-1912 : 1263-1278).

6. Günther's coursebook (1890) had its fifteenth edition or reprint in 1920. Likewise Grasé's coursebooks went through numerous editions/reprints between 1895 and 1930. 


\section{ABSTRACTS}

The drift of nearly all publications on the history of Dutch FLT is that the impact of the European Reform Movement (c1880-1910) was insignificant. However, the question is on what information this notion is based. From the comments of a number of persons who published their ideas during the 1930s - some 25 years after the Reform debate had fallen silent - it appears that their knowledge of the historical facts was small. And it seems that the comments of later critics are not based on proper research either. The question is if there was anything like a Dutch Reform Movement and, if so, in how far it was influenced by other European countries. Whoever wants to study the impact of the European Reform Movement on Dutch FLT should make systematic use of certain historical sources. This paper proposes four types of sources with which to address the research question. The paper first gives a brief sketch of the principles of the international Reform Movement. Next, it presents a picture of Dutch FLT around 1880. Finally, it describes the Dutch Reform in detail with the help of the aforementioned four types of sources. In the concluding paragraph I present my characteristic of the Movement in the Netherlands.

Presque toutes les publications concernant l'histoire de l'enseignement des langues étrangères aux Pays-Bas ont tendance à constater que l'influence du Mouvement européen de Réforme (1880-1920) a été sans importance. Seulement, la question est de savoir comment les auteurs arrivent à cette conclusion. Les commentaires de certains auteurs ayant publié leurs idées pendant les années 1930 - quelque 25 ans après la fin des discussions sur la Réforme - prouvent que leurs connaissances des faits historiques étaient insuffisantes. Les publications ultérieures ne sont pas non plus basées sur des recherches adéquates. La question est de savoir s'il y a eu vraiment un Mouvement de Réforme aux-Pays-Bas et si ce mouvement a été influencé par d'autres pays européens. Quand on étudie l'inluence de la Réforme de l'enseignement des langues aux Pays-Bas, il faut faire un usage systématique de certaines sources historiques. Cet exposé propose quatre catégories de sources. Il commence par une esquisse sommaire des principes du Mouvement de Réforme international. Ensuite il brosse un tableau de l'enseignement des langues étrangères aux Pays-Bas vers 1880. Enfin il décrit en détail la Réforme aux Pays-Bas à l'aide des quatre sources mentionnées plus haut. Le paragraphe final présente mes conclusions concernant les caractéristiques particulières du Mouvement aux Pays-Bas.

\section{INDEX}

Mots-clés: Réforme, allemand langue étrangère, enseignement de l'allemand, Pays-Bas

Keywords: Reform movement, Dutch foreign language teaching, Netherlands

\section{AUTHOR}

\section{FRANS WILHELM}

University of Arnhem and Nijmegen 